\title{
Exploring Cross-Racial Contact: Implications for PETE Pre-Service Teachers’
}

\section{Color-blind Racial Attitudes}

\author{
Dr. Joe W. Burden, Jr., Ph.D. (Corresponding author) \\ Child, Family, and Community Sciences, University of Central Florida \\ Orlando, Florida, 32816-1250 United States
}

Tel: 1-407-823-1401Ｅ-mail: joe.burden@ucf.edu/joe.burden.jr@gmail.com

Received: September 4

doi:10.5296/jse.v1i1.928
Accepted: September 16

Published: December 1, 2011

URL: http://dx.doi.org/10.5296/jse.v1i1.928

\begin{abstract}
The present study examined differences in color-blind racial attitudes based on reported levels of cross-racial contact in a sample $(n=239)$ of physical education teacher education (PETE) pre-service teachers. test analysis were utilized to assess differences between pre-service teachers whom reported either frequent cross-racial contact or non-frequent cross-racial contact in various settings (previous k-12 schooling, college courses, and home community) during their life experiences. Participants responded to the Color-blind Racial Attitudes Scale (CoBRAS), and a demographic survey which collected self-reported level of cross-racial contact. T-test results indicated a significant effect across each of the three settings, as collectively pre-service teachers perceiving to have had frequent cross-racial contact in academic and community settings revealed significantly lower color-blind racial attitudes than their counterparts whom collectively perceived non-frequent cross-racial contact across these settings. Overall, the findings in this study appear to support the theoretical utility of contact hypothesis as a method for reducing racial prejudice and biased attitudes.
\end{abstract}

Keywords: Color-blind racial ideology, Contact hypothesis, Cross-racial contact 


\section{Introduction}

Teacher education literature reveals that the overwhelming majorities of pre-service students in teacher education programs and $\mathrm{K}-12$ teachers in the United States (U.S.) are predominantly White American and female (National Center for Education Statistics, 2011), and in some instances have not received adequate preparation in teacher education programs to teach in racially and ethnically diverse classrooms (Atwater, 2008; Articles \& McClafferty, 1998; Burden, Hodge, O’Bryant, \& Harrison, 2004). In some instances, teacher educators and pre-service teachers fall prey of making broad generalizations about learners of particular ethnic, cultural, and linguistic backgrounds (Garmon, 2004; LeCompte \& McCray, 2002). Furthermore, a plethora of educators and scholars have expressed concerns related to the prevalence of color-blind policies and practices which repudiates the variety of learning styles related to culturally diverse students in U.S. schools (Atwater, 2008; Cross, 2003; Lewis, 2001). Thus, a plethora of literature has illuminated teacher educators and pre-service and novice teachers' need to prepare and utilize culturally relevant pedagogical practices to accommodate the diversity of learners in k-12 classrooms (Caniff, 2008; Ladson-Billings, 1995; Le Roux, 2001; Montecinos, 2004). Specific to physical education, Burden, et al. advocated for physical education teacher education programs (PETE) to pay special attention to implementing culturally relevant pedagogical preparation across PETE curriculum, in an effort to avoid the development of "color-blind" physical educators whom lack cross-cultural understanding or perpetuate preconceived physiological, social, or psychological stereotypic beliefs about their culturally diverse students in k-12 classrooms.

Teachers' beliefs are often shaped by the teachers' previous life histories and experiences as well as their experiences in PETE programs. If those histories or experiences do not include meaningful cross-racial contact with persons from varied ethnicities, cultures, or languages, these future teachers may be at a pedagogical disadvantage when they interact with students who are culturally, ethnically, and/or linguistically different from themselves (Burden et al., 2004). For instance, Harrison, Carson \& Burden (2010) found that White American k-12 physical education teachers' in racially heterogeneous settings held higher levels of multicultural teaching competence than those in racially homogenous settings. In addition, a cohort of literature forecasts positive benefits from meaningful interracial contact, such as reduced stereotypical perceptions towards African-Americans (Dixon and Rosenbaum, 2004), and improved views of racial policies towards African-Americans (Bobo \& Kluegel, 1997). Dixon \& Rosenbaum found that White Americans whom had more interaction with African Americans and Latinos within their communities and work environments were less likely to perpetuate stereotypical information regarding those racial groups.

Despite a body of literature suggesting cross-racial contact as a means for reducing racial prejudice and stereotypes, there is no prior empirical evidence in PETE literature to explain differences' in pre-service teachers' prior self reported cross-racial contact across various settings and its implications on their colorblind racial attitudes. Pre-service teachers' experiential limitations in racially and culturally diverse settings could predispose them to retrieve cognitive stereotypes when interacting with children of color (Milner, Flowers, Moore, \& Flowers, 2003). Therefore, obtaining knowledge about the dimensions of perceived life experiences with cross-racial contact in pre-service teacher's could have major 
implications for PETE teacher educators understanding of their social constructions as it may relate to their cross-cultural knowledge and beliefs. In an effort to better understand how pre-service students' prior self-reported cross-racial contact influenced their color-blind racial attitudes, two theoretical constructs guided the topics of investigation in this study. These theoretical paradigms included 1) color-blind racial ideology and 2) contact theory, also known as the "contact hypothesis".

\section{Contact Hypothesis: Reducing Racial Prejudice and Stereotypical Attitudes}

The 1940's and 1950's witnessed social challenges to the prevalence of a Jim Crow racially segregated America. For instance, acts such as military reform advocating racial integration in the U.S. Armed Forces following World War II, the migration of many southern African Americans to northern cities in search of economic mobility, and the 1954 Brown vs. Board of Education case were a few of many social events which fueled ethnic composition shifts in American social structures and increased the likeliness' for cross-racial contact (Brown \& Lopez, 2001). According to Key’s (1949) “Black Belt hypothesis”, as a result of integration White Americans who resided in close proximity to African Americans would be prone to have a more negative disposition towards them. A plethora of research emerged to validate Key's hypothesis claim and found that White Americans racial attitudes became increasingly more negative as they resided in areas with higher percentages of African Americans (Blalock, 1957; Fossett and Kiecolt 1989; Glaser, 1994). During the first half of the $20^{\text {th }}$ century, it is this disposition which would lead some White Americans to engage in race crimes, develop a resistance towards anti-racist policies, and advocate racist political parties and candidates, because of their fear that living amongst African Americans would devalue their political and financial privileges' in society (Glaser, 1994; Key, 1949).

Therefore, the second half of the $20^{\text {th }}$ century in the U.S. witnessed the birth of a social psychology research movement to better understand the context of reducing racial prejudice and discrimination in American culture (Allport, 1954). Gordon Allport 's (1954) publication titled, "The Nature of Prejudice” was instrumental in the development of intergroup contact theory or also known as the contact hypothesis, which proposes intergroup contact as an effective method for improving interethnic relations by decreasing the prevalence of prejudice and stereotyping between ethnic groups (Dixon, 2006; Pettigrew, 1998; Troop \& Bianchi, 2006). The initial belief adopted by most social scientists was that increasing cross-racial contact between groups would serve as an appropriate method for facilitating improvements in cross-racial relations through providing those groups assimilated experiences and interactions, which would disconfirm previously held prejudicial biases and stereotypes about each other (Allport, 1954; Brown \& Lopez, 2001; Pettigrew \& Troop, 2000). In fact, Brown \& Lopez (2001) described social scientists perspectives during this movement by indicating that:

Many social scientists assumed that European Americans held negative attitudes toward African Americans and other groups of color because they were ignorant of those groups. If European Americans became familiar with members of other ethnic groups and experienced commonalities, it was believed that their view of these outgroups would improve... at that time in U.S. history, contact and 
interpersonal closeness between European Americans and people of color often was minimal, given legal segregation and other formal and informal institutional structures. However, many social scientists believed that intergroup contact was a means of improving intergroup relations because it would either reveal interpersonal similarities or create them through the process of assimilation (p. 281). Though initially, contact theory was created to describe anti-black prejudice, its premise suggests that increasing contact between any racial and ethnic group members will expose them to new information about these groups, which would hopefully disconfirm negative stereotypes and stimulate positive perspectives in regard to various racial and ethnic groups (Dixon \& Rosenbaum, 2004).

\section{Color-blind Racial Ideology: Implications for Culturally Relevant Pedagogy}

\subsection{What is Color-blind Racial Ideology?}

Research related to the understanding of color-blind racial ideology has received considerable attention in the psychology literature (Atwater, 2008; Cornell, Park, \& Smith, 2008; Fryberg \& Stephens, 2010; Gutiérrez, \& Unzueta, 2010; Neville, Coleman, Falconer, \& Holmes, 2005; Neville, Lilly, Duran, Lee, \& Browne, 2000; Neville, Worthington, \& Spanierman, 2001; Ryan, Hunt, Weible, Peterson, \& Casas, 2007; Stephan \& Stephan, 2000; Tynes \& Markoe, 2010). Specifically, color-blind racial ideology has been measured in terms of color-blind racial attitudes. Color-blind racial attitudes (CoBRA) emerged in the psychology literature as a promising theoretical concept of characterized racial attitudes and awareness (Neville, Lilly, Duran, Lee, \& Browne, 2000). Neville et al. (2001) imply that understanding CoBRA are important in assessing ones awareness of racial oppression because it is able to attend to or process cognitive information on racial oppression.

Neville et al. (2001) revealed that CoBRA consists of four main tenets. These include 1) CoBRA are new forms of racial attitudes that are separate from, but related to racial prejudice 2) CoBRA are cognitive schemas, which reflect a conceptual framework and corresponding affect 3) CoBRA are complex and reflect multiple racial beliefs and 4) CoBRA are expressed differently between Whites and people of color. Furthermore, Neville, et al. (2001) assert that for White Americans color-blindness serves to legitimize racism by ignoring other ethnicities to protect group interest and maintain racial privilege. Thus, CoBRA proposes that the dominant U.S. racial ideology seeks to deny or minimize the facts that racial/ethnic minorities are victims of systematic racism and creates the attitude that fosters victims as the blame for their disparities in society. For example, color-blind ideology may be illustrated by some Whites in American society whom perpetuate stereotypical notions such as African Americans and Latinos don't work hard enough as the reason for their own educational and economic disparities when compared to by some Whites in American society (Bobo \& Kluegel, 1997). Atwater (2008) implies

Why the crusade for color-blindness? Within the American democratic ideal, the notion that skin color "should not and does not matter" fits in nicely with the "American" value of the importance of the individual over and above group membership. Indeed, if America had indeed met this vision of a democratic ideal, there would be no discrimination based on skin color 
and thus no need to recognize it- in employment, government, and in education.

\subsection{Correlation between CoBRA and Multicultural Teaching Competence}

Data reveals that a link exists between color-blind racial attitudes and greater levels of racial prejudice (Neville, Lilly, Duran, Lee, and Browne, 2000, Neville, Coleman, Falconer, \& Holmes, 2005). Neville, et al. (2000) found that among a predominantly White American sample, greater color-blind racial beliefs were correlated with a) racial intolerance b) racism against African Americans and c) beliefs that the world was socially just. In addition, Spainerman \& Heppner (2004) found that higher beliefs in colorblindness were related to increased anxiety and fear of ethnic minorities amongst White American college students. The significance between racial attitudes and multicultural competence in educational settings have been highlighted by a variety of educational and psychology scholars (Carter 1995, Sheets \& Hollins, 1999; Neville, Worthington, \& Spainerman, 2001). These researchers support the notion that the more aware White Americans are of their racial privileges and social identities, the more competent they will serve as teachers of diverse groups. For instance, Pohan (1996) studied 492 prospective teachers to assess variables' which influenced their multicultural awareness and sensitivity. Pohan found that students who brought stronger biases and racial stereotypes about teaching students of color were less likely to develop multicultural teaching competence.

\section{Research Purpose}

The purpose of the current study was to assess collective differences in pre-service teachers color-blind racial attitudes based on their self reported levels of cross-racial contact (non-frequent or frequent). The physical education teacher education literature is scare in terms of exploring cross-racial contact and color-blind racial ideology as theoretical constructs. Acquiring this information would add insight to the current PETE literature because little is known regarding PETE pre-service teachers' self reported levels of cross-racial contact and its influence on their color-blind racial attitudes and beliefs.

\section{Research Methodology}

\subsection{Participants and Procedures}

A list of PETE programs were located via an internet website search of accredited U.S. K-12 physical education teacher education programs. Following this search, the investigator contacted PETE program coordinators and department chairs and received permission from (5) programs throughout the Northeast region of the United States, to recruit and administer the color-blind racial attitudes scale (CoBRAS) to their pre-service teachers. Following approval from the university IRB committee, the investigator attended each of the 5 institutions and administered the CoBRAS to pre-service students within these programs.

The study involved 239 participants consisting of 142 male (59.4\%) and 93 female (38.9\%) physical education pre-service students enrolled in PETE programs in the Northeast region of the US. Four (1.7\%) participants choose not to report gender status. The mean age of the participants was 23.6 years old $(\mathrm{SD}=4.7)$ with a range of 19 to 52 years old. Participants represented a variety of racial and ethnic backgrounds, consisting predominately of White American ( $n=204,85.4 \%)$, followed respectively by Hispanic/Latina/o $(n=20,8.4 \%)$, 
African American ( $\mathrm{n}=9,3.7 \%)$, (Asian American $(\mathrm{n}=2,0.8 \%)$; Native American $(\mathrm{n}=1$, $0.4 \%$ ); and multi-racial ( $\mathrm{n}=3,1.3 \%$ ). Three $(1.3 \%)$ participants choose not to report ethnicity status. The mean age of the participants was 23.6 years old, with a range of 19-52 years old. In compliance with the ethical standards of research, all individuals' participated in the study on a voluntary basis, were informed of the study and signed consent forms, were debriefed following the research process, and were ensured that their personal identity would remain confidential in the presentation of data results of the study.

\subsection{Instruments}

A self report questionnaire, the color-blind racial attitude scale (CoBRAS) was distributed to pre-service teachers. The scale was chosen because it measures the theoretical construct of color-blind racial attitudes, which is of concern to this investigation. The CoBRAS scale was constructed and initially validated by Neville, Lilly, Duran, Lee, \& Browne (2000) to examine the self-reported degree to which participants' deny, distort, and minimize aspects of racial awareness or institutional racism. Previously, CoBRAS has been found to be highly reliable with various populations in psychology and education settings. Atlwater (2007) reported that CoBRAS reliability coefficients (Cronbach, 1951) (Cronbach's alpha) have been found to hold strong psychometric validity; 0.91 (Neville et al, 2000), and in the present study 0.74 , which adheres to Nunnaly’s (1978) .70 criterion standard to establish internal consistency and reliability in psychometric scales. Since its conception, scholars have utilized the CoBRAS to assess racial attitudes in participants (Neville, et al, 2001; 2005, 2006). The CoBRAS consists of 20 items, which are rated on a 6-point Likert scale ranging from 1 (strongly disagree) to 6 (strongly agree).

For purposes of this study, the researcher adhered to previous researchers (Neville, Coleman, Falconer, \& Holmes, 2005) method of assessing COBRAS by examining the total score of the COBRAS. There were 20 items ranging from 1-6, therefore total scores on the MTCS range from 20 to 120, with the higher scores indicating greater denial to the existence of institutional racism. Specifically, the CoBRAS model has been related to social attitude indexes which include increased levels of internal racial oppression, anti-egalitarian beliefs, and victim blame ideology among people of color (Neville et al., 2006). Thus, the CoBRAS was utilized to further our understanding of differences in pre-service teachers' racial attitudes and its measure of relationship to their self-reported prior cross-racial contact across various settings

\subsection{Assessment of Prior Cross-Racial Contact}

The pre-service students were administered a survey which included a chart. They were asked to report their perceived level of cross-racial contact (non-frequent vs. frequent) in three social settings (1) prior K-12 experiences, (2) during college classes, and (3) current residential communities. Similar to Emerson, Kimbro \& Yancy (2002) method of analysis for prior racial contact, our measurements of prior racial contact were crude and not specifically detailed. Therefore, measurements of prior racial contact were not defined objectively but subjectively by the student, thus, participants were given freedom to determine their level of cross-racial contact (either frequent or non-frequent) from their life experiences and views.

\subsection{Hypothesis \& Data Analysis}


Three separate hypothesis tests were performed on the data collected. Thus, (3) non-directional two-tailed independent samples unpaired t-tests were performed, comparing means of color-blind racial attitudes (CoBRAS mean scores) between pre-service teachers' level of self reported cross-racial contact (non-frequent vs. frequent) across three settings. The researchers utilized the unpaired $t$ method to examine the null hypothesis that the CoBRAS means related to the two independent (frequent and non-frequent cross-racial contact self-reporting pre-service teachers) samples of pre-service teachers were equal (Trochim, 2006). Specifically, we tested the following three test hypotheses in this study.

$\mathrm{H}_{0}: \rho=0.0$ (Null hypothesis)

HA: $\rho \neq 0$ (Alternative Hypothesis)

Test Hypothesis 1

$\mathrm{H}_{\mathrm{o}}$ : There is not a significant difference in colorblind racial attitude mean scores between pre-service teachers whom self reported having non-frequent or frequent cross-racial contact during their previous k-12 schooling experiences.

HA: There is a significant difference in colorblind racial attitude mean scores between pre-service teachers whom self reported having non-frequent or frequent cross-racial contact during their previous k-12 schooling experiences.

Test Hypothesis 2

$\mathrm{H}_{\mathrm{o}}$ : There is not a significant difference in colorblind racial attitude mean scores between pre-service teachers whom self reported having non-frequent or frequent cross-racial contact within their previous college courses.

HA: There is a significant difference in colorblind racial attitude mean scores between pre-service teachers whom self reported having non-frequent or frequent cross-racial contact within their previous college courses.

Test Hypothesis 3

$\mathrm{H}_{\mathrm{o}}$ : There is not a significant difference in colorblind racial attitude mean scores between pre-service teachers whom self reported having non-frequent or frequent cross-racial contact within their previous resident communities.

HA: There is a significant difference in colorblind racial attitude mean scores between pre-service teachers whom self reported having non-frequent or frequent cross-racial contact within their previous residential communities.

\section{Results}

Out of the 239 participating pre-service teachers, $99.6 \%(n=238)$ of the participants self reported cross-racial contact in their college classes $(0.4 \%$ failed to report racial contact in their college classes), $98.7 \%(\mathrm{n}=236)$ of participants self reported cross-racial contact in their k-12 experiences ( $1.3 \%$ failed to report racial contact in $k-12$ ), and $98 \%(n=234)$ of participants self reported their cross-racial contact in their residential communities ( $2 \%$ failed to report racial contact in their residential areas).

Specifically, this study assessed if there were statistically significant differences collectively between pre-service teachers colorblind attitude mean scores in regard to self reported levels of cross-racial contact (non-frequent or frequent) across three contact situations; (1) previous 
k-12 schooling experiences, (2) college classes, and (3) residential communities. Results indicated to reject the (null hypothesis) for each of the three t-test, and revealed significantly lower CoBRAS mean scores among pre-service teachers whom collectively self reported having frequent cross-racial contact across the three contact situations than those collectively self reporting non-frequent cross-racial contact across; (1) previous K-12 schooling: t (234) = 2.004, $\mathrm{p}<.0046, \quad(2)$ college classes: $\mathrm{t}(236)=2.172, \mathrm{p}<.0030$, and (3) residential community: $\mathrm{t}(232)=2.080, \mathrm{p}<.0038$.

\subsection{Cross-Racial Contact in Previous K-12 Schooling Experiences}

$60 \%(n=142)$ of the PETE students reported having frequent and $39.8 \%(n=94)$ reported non-frequent cross-racial contact during their k-12 school experiences. In addition, .02\% $(n=3) \%$ failed to report their cross-racial contact during their k-12 school experiences. Analysis of the first unpaired t-test revealed a significant effect for level of cross-racial contact, as collectively pre-service teachers self reporting frequent cross-racial contact during their schooling experiences held significantly lower levels of colorblind racial attitudes $(\mathrm{M}=69.96, \mathrm{SD}=10.95)$ than those self reporting non-frequent cross-racial contact during their $\mathrm{k}-12$ schooling experiences $(\mathrm{M}=72.81, \mathrm{SD}=10.22), t(234)=2.004, \mathrm{p}<0.01$.

\subsection{Cross-Racial Contact in College Courses}

In regards to the pre-service students cross-racial contact in college courses, $(n=136) 57 \%$ reported frequent cross-racial contact, $(n=102) 42.6 \%$ reported non-frequent cross-racial contact, and $(n=1) .04 \%$ failed to report cross-racial contact in their college courses. Analysis of the second unpaired t-test revealed there was a significant effect for level of cross-racial contact, as collectively pre-service teachers whom self reported to have had frequent cross-racial contact during college courses reported significantly lower levels of colorblind racial attitudes $(\mathrm{M}=69.88, \mathrm{SD}=9.78)$ than those reporting to have had non-frequent cross-racial contact during their collegiate experiences $(\mathrm{M}=72.74, \mathrm{SD}=10.32), t(236)=2.172$, $\mathrm{p}<0.01$.

\subsection{Cross-racial contact in residential communities}

$50 \%(n=119)$ of the pre-service teachers reported non-frequent cross-racial contact, $(n=115)$ $48 \%$ reported frequent interracial contact, and $(n=4) 2 \%$ failed to report their cross-racial contact in their places of residence. Furthermore, data from the third unpaired t-test revealed that collectively, pre-service teachers self reporting frequent cross-racial contact reported significantly lower colorblind racial attitudes $(M=69.66, S D=10.59)$ than those reporting non-frequent cross-racial contact within their residential areas $(\mathrm{M}=72.38, \mathrm{SD}=10.59), t(232)$ $=2.080, \mathrm{p}<0.01$.

\section{Discussion}

\subsection{Interracial Contact in K-12 Schooling}

The first test null hypothesis in this study was rejected, as t-test analysis revealed that pre-service students self reporting frequent cross-racial contact held significantly less color-blind racial attitudes than pre-service students self reporting non-frequent cross-racial contact during their previous k-12 school experiences. This finding is consistent with the premises of contact theory and a cohort of literature which reveals that white students in racially integrated k-12 settings exhibit more racial tolerance and less fear of their African 
Americans peers over time than did their White American peers within segregated settings (Mcglothlin, Killen, \& Edmonds, 2005; Schofield, 1989; 1995).

Over a third, (40\%) of the pre-service teachers self reported to have had non-frequent cross-racial contact during their prior k-12 schooling experiences. This finding may be alarming but should not be surprising as Ebert (2004) reported that opportunities for cross-racial contact during childhood is limited and only 2 out of every 10 children nationwide have the opportunity for cross-racial contact. Therefore, PETE teacher educators should aspire to develop a better understanding of their pre-service students' social constructions during their elementary and secondary schooling experiences, as this could provide valuable information about their (pre-service students) knowledge, attitudes, and values of culturally diverse individuals. For instance, a cohort of empirical research has shown that children exposed to cross-racial interaction and friendships during elementary school are able to more effectively develop positive attitudes and behaviors towards members of other racial groups (Schofield, 1989; Turner, Hewstone, \& Voci, 2007). For example, Mcglothlin, et al. study on children's implicit attitudes about racial peers found that white students in racially homogeneous elementary schools were more likely to attribute negative aspirations to peers on the basis of race when asked to assess situational scenarios in school settings, than were white students in racially heterogeneous schools. Stearns, Furthermore Buchmann, \& Bonneau (2009) found that one's cross-racial interactions acquired during their k-12 school experiences were significantly associated with their likelihood to establish cross-racial friendships during college.

\subsection{Cross-Racial Contact in College Courses}

The second test null hypothesis in this study was rejected, as analysis of the second unpaired t-test revealed that collectively pre-service students self reporting frequent cross-racial contact held significantly less color-blind racial attitudes than pre-service students self reporting non-frequent cross-racial contact in their college classes. Our findings were consistent with previous studies which reveal the positive benefits of cross-racial contact on college students' racial awareness and openness to diversity (Chang, Denson, Saenz, \& Misa, 2006; Levin, van Laar, \& Sidanius, 2003; Schofield, Hausmann, Ye, \& Woods, 2010). Chang, (2007) asserted:

cross-racial interaction is a key form of student engagement that has been shown by a large number of independent studies to have a significant positive effect on a range of educational outcomes. In Making Diversity Work on Campus, we noted strong evidence that the frequency of cross-racial interaction that occurs during the normal course of undergraduate life contributes in positive ways to students' learning and educational experiences (p.28).

Though research specifies that student diversity in college is beneficial for developing student's awareness and receptivity to racial and cultural issues, we should note not all PETE programs are presented with the opportunity to have a wide array of student diversity within their programs. As aforementioned in this paper, there are a lack of students of color in k-12 teacher education programs, as reflected by the $85 \%$ representation of White American pre-service teacher subjects in this study and over a third (42\%) of pre-service teachers reporting non-frequent interracial contact during their college courses. Thus, teacher 
educators in predominantly White PETE programs should be cognizant to create cross-racial and cross-cultural dialogue during PETE curricular courses, which could serve as a strategy to facilitate PETE pre-service teachers understanding about cultural based experiences, inequalities, and differences in norms, as it relates to other races and ethnicities. For instance, Kerrsen-Griep \& Eifler's (2008) longitudinal study evaluated behavioral changes in communication skills of White pre-service teachers while serving 8 months as academic mentors for a group of African American students. Specifically, Kerrsen-Griep \& Eifler reported that the cross-racial contact resulting from the cross-cultural teacher training intervention was beneficial for creating positive change in the pre-service teachers' behaviors and attitudes during cross-racial communications, and facilitated their awareness of institutionalized racism and cultural competence. Thus, there may be positive behavioral changes that may occur from increasing cross-racial contact, as results in this study indicate significantly lower color-blind attitudes for those pre-service teachers whom perceived to have more cross-racial contact in college courses.

\subsection{Interracial Contact in Residential Settings}

Findings in this study reveal that half (50\%) of the pre-service students reported non-frequent cross-racial contact in communities where they resided. This finding was consistent with premises of contact hypothesis, as results revealed significantly less color-blind attitudes collectively among pre-service students reporting frequent cross-racial contact in areas where they reside. In addition, this finding is also aligns with a cohort of research which reveals the positive effects of cross-racial contact and positive attitudes towards ethnically diverse people in residential areas (Stein, Post, and Rinden, 2000; Taylor, 1998; Weaver, 2007).

Specifically, research has shown that increasing cross-racial friendships through contact in residential areas has improved implicit attitudes towards those out-groups (Aberson \& Haag, 2007), though it should be noted that friendships may increase cross-racial contact conditions and lead to more reduction of prejudice than cross-racial contact without friendship (Pettigrew \& Tropp, 2000). Thus, providing PETE teachers with field experiences that involve cross-racial and cultural interaction with students' families and friends in diverse residential areas could be explored as a method to reduce color-blind racial attitudes and prejudices. It is intended that these types of contact engagements in k-12 students residential communities (i.e., outside the school environment) could potentially increase future teachers' effectiveness' in working with children of all racial and ethnic backgrounds in American schools.

\section{Limitations}

The research failed to identify objective measures of cross-racial contact across the three various contact situations because it allowed for subjectivity in the reporting of cross-racial contact on two levels (non-frequent and frequent contact). Thus, several limitations in this study involved the lack of understanding variables such as the frequency and duration of cross-racial contact that the pre-service teachers determined as frequent or non-frequent. In addition, a limitation includes the failure to include data analysis of potential differences in color-blind attitudes based on socio-economic status, level within the PETE program, age, race, and gender. Future cross-racial studies should include these factors to provide a more 
comprehensive and dynamic understanding of the influence of cross-racial contact in the development of racial attitudes and beliefs.

\section{Conclusions}

The present study was able to shed light on differences in PETE pre-service teachers' color-blind racial attitudes and beliefs based on their self reported degree of cross-racial contact across various settings. Forbes (1997) literature review on cross-racial contact indicated that over $90 \%$ of interracial contact studies revealed positive effects. Overall, the findings in this study appear to support the theoretical utility of contact hypothesis as a method for reducing racial prejudice and biased attitudes. Consistent with other contact studies, it also appears that interracial contact had positive effects on racial attitudes in this study, as the findings suggest that collectively PETE pre-service students' self-reporting frequent cross-racial contact reported significantly less color-blind racial attitudes than those whom self-reported as having non-frequent cross-racial contact across each of the contact situations identified within this study.

In addition, the findings reveal the relevance of incorporating cross-cultural interactions and communications within teacher education curricula and field experiences, as it appears these interactions may facilitate cross-racial awareness among pre-service teachers. Thus, implementation of culturally relevant curricula practices which increase pre-service teachers' opportunities for interracial contact could serve as beneficial for improving their racial awareness of issues of social and racial inequality exhibited in K-12 education settings.

In closing, teacher educators must develop ways to prepare themselves to improve their multicultural knowledge, in an effort to transfer it to PETE pre-service students in their programs. Efforts of this nature would assure, as advocated by Burden, et al. (2004) that PETE programs move from a state of 'color-blindness' to intercultural sensitivity in their preparation of pre-service teachers. Further study in this area would be beneficial because knowledge about cross-racial contact could provide for a better understanding of how pre-service teachers' social construction influences their development of cross-racial awareness, attitudes, and beliefs.

\section{References}

Aberson, C. L., \& Haag, S. C. (2007). Contact, anxiety, perspective taking, and stereotype endorsement as predictors of implicit and explicit biases. Group Processes and Intergroup Relations, 10, 179-201. http://dx.doi.org/10.1177/1368430207074726

Allport, G.W. (1954). The nature of prejudice. Reading, MA: Addison-Wesley.

Atwater, A. S. (2007). An investigation of teacher's 'color-blind' racial attitudes and diversity training experiences: Implications for teacher education. Journal of Education \& Human Development, 1(2), 1-15.

Atwater, A. S. (2008). Waking up to difference: Teachers, color-blindness, and the effects of students of color. Journal of Instructional Psychology,35(3), 246-253.

Articles, A. J. \& McClafferty, K. (1998). Learning to teach culturally diverse learners: 
Charting change in preservice teachers' thinking about effective teaching. The Elementary School Journal, 98(3), 189-220. http://dx.doi.org/10.1086/461891

Blalock, Jr., H. (1957). Per cent non-white and discrimination in the south. American Sociological Review, 22, 677-682.

Bobo, L., \& Kluegel, J. R. (1997). Status, ideology, and dimensions of Whites racial beliefs and attitudes: Progress and stagnation. In S.A. Tuch \& J.K. Martin (eds), Racial attitudes in the 1990's: Continuity and change (pp. 93-120). Westport, CT: Praeger.

Brown, L. \& Lopez, G. (2001), Political Contacts: Analyzing the role of similarity in theories of prejudice. Political Psychology, 22(2), 279-292.

http://dx.doi.org/10.1111/0162-895X.00239

Burden, Jr. J., Hodge, S. R., O’Bryant, C. P., \& Harrison, Jr., L. (2004). From colorblindness to intercultural sensitivity: Infusing diversity training in PETE programs. Quest, 56, 173-189.

Canniff, J. (2008). A cultural memoir of schooling: connecting history and critical reflection to the development of culturally responsive educators. Teaching Education, 19(4), 325-335. http://dx.doi.org/10.1080/10476210802436476

Carter, R.T. (1995). The influence of race and racial identity in psychotherapy. New York: Wiley.

Chang, M. (2007). Beyond artificial integration: Reimagining cross-racial interactions among undergraduates. New Directions for Student Services, 120, 25-37.

http://dx.doi.org/10.1002/ss.255

Chang, M., Denson, N., Saenz, V., \& Misa, K. (2006). The educational benefits of sustaining cross-racial interaction among undergraduates. The Journal of Higher Education, 77 (3), 430-455. doi:10.1353/jhe.2006.0018, http://dx.doi.org/10.1353/jhe.2006.0018

Cornell, J., Park, B., \& Smith, J. (2008).Colorblind and multicultural prejudice reduction strategies in high conflict situations. Group Processes Intergroup Relations, 11(4), 471-49. http://dx.doi.org/10.1177/1368430208095401

Cronbach, L. J. (1951). Coefficient alpha and the internal structure of tests. Psychometrika. 16, 297-334.

Cross, B. (2003). Learning or unlearning racism: Transferring teacher education curriculum to classroom practices. Theory into Practice, 42(3), 203-210.

http://dx.doi.org/10.1353/tip.2003.0027

Dixon, J. (2006). The ties that bind and those that don't: Toward reconciling group threat and contact theories of prejudice. Social Forces, 84(4), 2179-2204.

http://dx.doi.org/10.1353/sof.2006.0085

Dixon, J. \& Rosenbaum, M. (2004). Nice to know you? Testing contact, culture, and group threat theories of anti-Black and anti-Hispanic stereotypes. Social Science Quarterly, 85 (2), 257-280. http://dx.doi.org/10.1111/j.0038-4941.2004.08502003.x 
Ebert, K. L. (2004). Interracial contact and racial attitudes: A comparative study of Asian, Black, and White Youth. [Online] Available:

http://www.allacademic.com/meta/p110736_index.html

Emerson, M., Kimbro, R., \& Yancey, G. (2002). Contact theory extended: The effects of prior racial contact on current social ties. Social Science Quarterly, 83 (3), 745-761.

http://dx.doi.org/10.1111/1540-6237.00112

Forbes, H. D. (1997). Ethnic Conflict. New Haven: Yale University Press.

Fossett, M. \& Kiecolt, K. J. (1989). The relative size of minority populations and White racial attitudes. Social Science Quarterly, 60, 50-66.

Foster, M., Lewis, J., \& Onafowora, L. (2003). Anthropology, culture, and research on teaching and learning: Applying what we have learned to improve practice. Teachers College Record, 105(2), 261-277. http://dx.doi.org/10.1111/1467-9620.t01-1-00239

Fryberg, S., \& Stephens, N. (2010). When the world is colorblind, American Indians are invisible: A diversity science approach. Psychological Inquiry, 21(2), 115-119.

http://dx.doi.org/10.1080/1047840X.2010.483847

Garmon, M. A. (2004). Changing Preservice teachers' attitudes/beliefs about diversity: What are the critical factors? , Journal of Teacher Education, 55(3), 201-213.

http://dx.doi.org/10.1177/0022487104263080

Glaser, J. (1994). "Back to the black Belt: Racial environment and White racial attitudes in the south.” Journal of Politics, 56, 21-41. http://dx.doi.org/10.2307/2132344

Gutiérrez, A., \& Unzueta, M. (2010). The effect of interethnic ideologies on the likability of stereotypic vs. counterstereotypic minority targets. Journal of Experimental Social Psychology, 46 (5), 775-784. doi:10.1016/j.jesp.2010.03.010

Harrison, Jr., L., Carson, R. L., \& Burden, Jr. J. (2010). Physical education teachers' cultural competency. Journal of Teaching in Physical Education, 29, 184-198.

Housee, S. (2008). Should ethnicity matter when teaching about race and racism in the classroom? Race, Ethnicity, and Education, 11(4), 415-428. http://dx.doi.org/10.1080/13613320802478960

Kerrsen-Griep, J., \& Eifler, K. (2008). When Cross-Racial Contact Transforms Intercultural Communication Competence: White novice teachers learn alongside their African American high school mentees. Journal of Transformative Education, 6(4), 251-269.

Key, V. O. (1949). Southern Politics in State and Nation. New York: Knopf.

Ladson-Billings, G. (1995). But that's just good teaching: The case for culturally relevant pedagogy. Theory into Practice, 34(3), 159-165.

http://dx.doi.org/10.1080/00405849509543675

LeCompte, K., \& McCray, A., (2002). Complex conversations with teacher candidates: 
Perspectives of Whiteness and culturally responsive teaching. Curriculum and Teaching Dialogue, 4(1), 25-35. doi:10.1080/00405849509543675

Le Roux, J. (2001). Effective schooling is being culturally responsive. Intercultural Education, 12(1), 41-50. http://dx.doi.org/10.1080/14675980120033957

Lewis, A. (2001). There is no "race" in the schoolyard: Color-blind ideology in an (almost) all-white school. American Education Research Journal, 38(4), 781-811. http://dx.doi.org/10.3102/00028312038004781

Levin, S., van Laar, C., \& Sidanius, J. (2003). The effects of ingroup and outgroup friendship on ethnic attitudes in college: A longitudinal study. Group Processes and Intergroup Relations, 6, 76-92. http://dx.doi.org/10.3102/00028312038004781

Mcglothlin, H., Killen, M., \& Edmonds, C. (2005). European-American children's intergroup attitudes about peer relationships. British Journal of Developmental Psychology, 23(2), 227-249. http://dx.doi.org/10.1348/026151005x26101

Milner, H. R., Flowers, L., Moore, E., \& Flowers (2003). Preservice teachers’ awareness of multiculturalism and diversity. High School Journal, 87(1), 63-70.

http://dx.doi.org/10.1353/hsj.2003.0018

Montecinos, C. (2004). Paradoxes in multicultural teacher education research: students of color positioned as objects while ignored as subjects. International Journal of Qualitative Studies in Education, 17(2), 167-181. http://dx.doi.org/10.1080/09518390310001653853

Neville, H.A., Coleman, M.N., Falconer, J.W., \& Holmes, D. (2005). The relations between color-blind racial ideology and psychological false consciousness among African Americans. Journal of Black Psychology, 31, 27-45. http://dx.doi.org/10.1177/0095798404268287

Neville, H.A., Spainerman, L., \& Doan, B-T. (2006). Exploring the association between color-blind racial ideology and multicultural counseling competencies. Cultural Diversity and Ethnic Minority Psychology, 12(2), 275-290. http://dx.doi.org/10.1037/1099-9809.12.2.275

Neville, H.A., Lilly, R.L., Duran, G., Lee, R.M., \& Browne, L. (2000). Construction and initial validation of the color-blind racial attitudes scales (CoBRAS). Journal of Counseling Psychology, 47(1), 59-70. http://dx.doi.org/10.1037//0022-0167.47.1.59

Neville, H. A., Worthington, R. L., \& Spanierman, L.B. (2001). Race, power, and multicultural counseling: Understanding White privilege and color-blind racial attitudes. In J.G. Ponterotto, J.M., Casas, L.A. Suzuki, \& C.M. Alexander (eds.) Handbook of multicultural counseling psychology. ( $2^{\text {nd }}$ ed) CA: Sage. (pg. 257-288)

Nunnally, J. C. (1978). Psychometric theory (2nd Ed.). New York: McGraw-Hill.

Pettigrew, T.F. (1998). Intergroup contact theory. Annual Review of Psychology, 49, 65-85. http://dx.doi.org/10.1146/annurev.psych.49.1.65

Pettigrew, T.F., \& Tropp, L.R. (2000). Does intergroup contact reduce prejudice? Recent meta-analytic findings. In S. Oskamp (Ed.), Reducing prejudice and discrimination: Social 
psychological perspectives (pp. 93-114). Mahwah, NJ: Erlbaum.

Plant, E. A. \& Devine, P. G. (1998). Internal and external motivation to respond without prejudice. Journal of Personality and Social Psychology, 75, 811-832.

http://dx.doi.org/10.1037//0022-3514.75.3.811

Pohan, C. A. (1996). Preservice teachers' beliefs about diversity: Uncovering factors leading to multicultural responsiveness. Equity and Excellence in Education, 29(3), 62-69. http://dx.doi.org/10.1080/1066568960290310

Ryan, C., Hunt, J., Weible, J., Peterson, C., \& Casas. J. (2007). Multicultural and colorblind ideology, stereotypes, and ethnocentrism among black and white Americans. Group

Processes Intergroup Relations, 10 (4), 617-637.

http://dx.doi.org/10.1177/1368430207084105

Schofield, J.W., Hausmann, L., Ye, F., \& Woods, R. (2010). Intergroup friendships on campus: Predicting close and casual friendships between White and African American first-year college students. Group Processes Intergroup Relations, 13(5), 585-602.

http://dx.doi.org/10.1177/1368430210362437

Schofield, J. W. (1995). Review of Research on School Desegregation's Impact on Elementary and Secondary School Students. In ed. James A. Banks \& Cherry M. Banks, Handbook of Research on Multicultural Education (pp.597-616). New York: Macmillan Publishing.

Schofield, J. W. (1989). Trust, Tension or Tolerance? New York: Teachers College Press.

Sheets, R, H. \& Hollins, E. R. (Eds) (1999). Aspects of human development: Racial and ethnic identity in school practices. Mahwah, NJ: Erlbaum.

Sowers, J. (2004). Creating a community of learners: Solving the puzzle of classroom management. Portland, OR: Northwest Regional Educational Laboratory

Spanierman, L. B. \& Heppner, M. J. (2004). Psychosocial costs of racism to Whites Scale (PCRW): Construction and initial validation. Journal of Counseling Psychology, 51, 249-262. http://dx.doi.org/10.1037/0022-0167.51.2.249

Stearns, E., Buchmann, C. \& Bonneau, K. (2009). Interracial friendships in the transition to College: Do birds of a feather flock together once they leave the nest? Sociology of Education, 82(2), 173-195. http://dx.doi.org/10.1177/003804070908200204

Stein, R., Post, S., \& Rinden, A. (2000). Reconciling context and contact effects on racial attitudes. Political Research Quarterly, 53, 285-303.

http://dx.doi.org/10.1177/106591290005300204

Stephan, W. G., \& Stephan, C. W. (2000). An integrated threat theory of prejudice. In S. Oskamp (Ed.) Reducing Prejudice and discrimination (pp. 23-45). Mahwah, NJ: Lawrence Erlbaum Associates.

Taylor, M. (1998). How White attitudes vary with the racial composition of local populations: 
Numbers count. American Sociological Review, 63, 512-535.

Trochim, W. (2006). Research Methods Knowledge Base. [Online] Available: http://www.socialresearchmethods.net/kb/index.php

Troop, L. \& Bianchi, R. (2006). Valuing diversity and interest in intergroup contact. Journal of Social Issues, 62(3), 533-551. http://dx.doi.org/10.2307/2657265

Turner, R., Hewstone, M., \& Voci, A. (2007). Reducing explicit and implicit prejudice via direct and extended contact: The mediating role of self-disclosure and intergroup anxiety.

Journal of Personality and Social Psychology, 93, 369-388.

http://dx.doi.org/10.1037/0022-3514.93.3.369

Tynes, B., \& Markoe, S. (2010). The role of color-blind racial attitudes in reactions to racial discrimination in social network sites. Journal of Diversity in Higher Education, 3(1), 1-13. http://dx.doi.org/10.1037/a0018683

U.S. Department of Education, National Center for Education Statistics. (2011): The Condition of Education. [Online] Available:

http://nces.ed.gov/pubsearch/pubsinfo.asp?pubid=2011033

Weaver, C. N. (2007). The effects of contact on the prejudice between Hispanics and nonHispanic Whites in the United States. Hispanic Journal of Behavioral Sciences, 29, 254-274. http://dx.doi.org/10.1177/0739986306296590

\section{Copyright Disclaimer}

Copyright reserved by the author(s).

This article is an open-access article distributed under the terms and conditions of the Creative Commons Attribution license (http://creativecommons.org/licenses/by/3.0/). 